\title{
Pigeon Pea for Africa: A Versatile Vegetable-And More
}

\author{
S.S. Snapp \\ Michigan State University, East Lansing, MI 48824 \\ R.B. Jones and E.M. Minja \\ International Crop Research Institute for the Semi-Arid Tropics (ICRISAT), Nairobi, Kenya \\ J. Rusike \\ International Crop Research Institute for the Semi-Arid Tropics (ICRISAT), Bulawayo, Zimbabwe \\ S.N. Silim \\ International Crop Research Institute for the Semi-Arid Tropics (ICRISAT), Nairobi, Kenya \\ Additional index words. tropical legume, Cajanus cajan, multi-use shrub, farmer adoption
}

\begin{abstract}
Pigeon pea is an important, multi-use shrub legume of the tropics and subtropics. It has a wide range of products, including the dried seed (primarily used as dahl, a processed, dehulled, split seed), pods and immature seeds used as green vegetables, leaves and stems used for fodder and soil improvement, and the dry stems as fuel (Fig. 1A). Production and acreage of pigeon pea is on the rise in Africa. This could be the decade in which pigeon pea becomes the primary high-protein (20\% to $32 \%$ ) vegetable in sub-Saharan Africa. It makes an outstanding contribution to home production systems by enhancing both human and soil nutrition. In addition to subsistence production, the pigeon pea export market from Africa has potential for further development (Jones et al., 2000). However, there are barriers to wider production of pigeon pea.
\end{abstract}

The wide adaptation and indispensable role of pigeon pea as a vegetable and grain legume for some of the poorest regions of the world was described by Morton in 1976. In the subsequent quarter-century, production has expanded beyond the subsistence level. In Kenya, for example, it is one of the fastest growing cash crops with an annual growth rate of 3\% over the last 15 years (Freeman et al., 1999). An expanding world market is providing this opportunity: the whole grain and processed grain is exported to the Indian diaspora, and vegetable products to Europe, Asia, and the Caribbean (Jones et al., 2002).

Surprisingly, research attention to pigeon pea remains limited. It is one of the world's oldest food crops and ranks fifth among edible legumes in worldwide production (Nene and Sheila, 1990), yet in a recent search of Agricola and $\mathrm{CAB}$ databases for research articles published in 2000 we found only 780 citations that mention pigeon pea, vs. 19,450 for common bean (Phaseolus vulgaris L.). Australia and India are two of the few countries to have made significant investments in pigeon pea research, along with the International Crops Research Institute for the Semi-Arid Tropics (Jones et al., 2000).

Received for publication 9 Sept. 2002. Accepted for publication 4 Feb. 2003.

\section{BIOLOGY AND ADAPTATION}

Pigeon pea is an erect shrub, a short-lived leguminous perennial that is managed in agricultural systems as an annual or biannual. It may reach $4 \mathrm{~m}$ in height, but is usually about $1.5 \mathrm{~m}$ (Fig. 1A). Woody at the base of the plant, the side branches are generally erect (Morton, 1976). The vertical taproot is deep and extensive, reaching depths of 1-2 $\mathrm{m}$, with multiple branches (Anderson et al., 2001; Sheldrake and Naranyanan, 1979). Maturity ranges from $\approx 90$ to $280 \mathrm{~d}$. Pigeon pea genotypes are generally grouped into four categories: extra short duration $(<105 \mathrm{~d})$, short duration $(\approx 105-145$ d), medium ( $\approx 146-199$ d), and late-maturing (>200 d) cultivars (van der Maesen, 1989). Other maturity classification systems have been proposed, with up to 10 categories (Reddy, 1990; Silim and Omanga, 2001). Shorter-duration lines frequently are determinate, although determinate and indeterminate growth habits occur across maturity groups.
Pigeon pea is a quantitative short-day plant. Genotypes tend to be extremely sensitive to photoperiod and temperature; this can greatly alter phenology, height, and productivity (Reddy, 1990). A transect study in Kenya demonstrated that slightly cooler average temperatures can dramatically delay maturity in short and extra-short duration cultivars; days to maturity were $94 \mathrm{~d}$ at $23^{\circ} \mathrm{C}$ vs. $175 \mathrm{~d}$ at $18{ }^{\circ} \mathrm{C}$ (Silim and Omanga, 2001). Delayed maturity frequently reduces yield because of late-season drought stress, and interferes with planting a subsequent crop.

Pigeon pea is unusually adaptable, flourishing in the dry as well as the wet tropics and sub-tropics. It is frost-sensitive, but can produce at a moderate yield level ( 0.2 to 2.5 $\left.\mathrm{t} \cdot \mathrm{ha}^{-1}\right)$ across an impressively broad range of environments (Degrande, 2001; Snapp and Silim, 2001; Versteeg and Koudokpon, 1993). In $2000, \approx 4.78$ million acres were reportedly planted around the world: this includes the Caribbean, selected regions in Africa, and

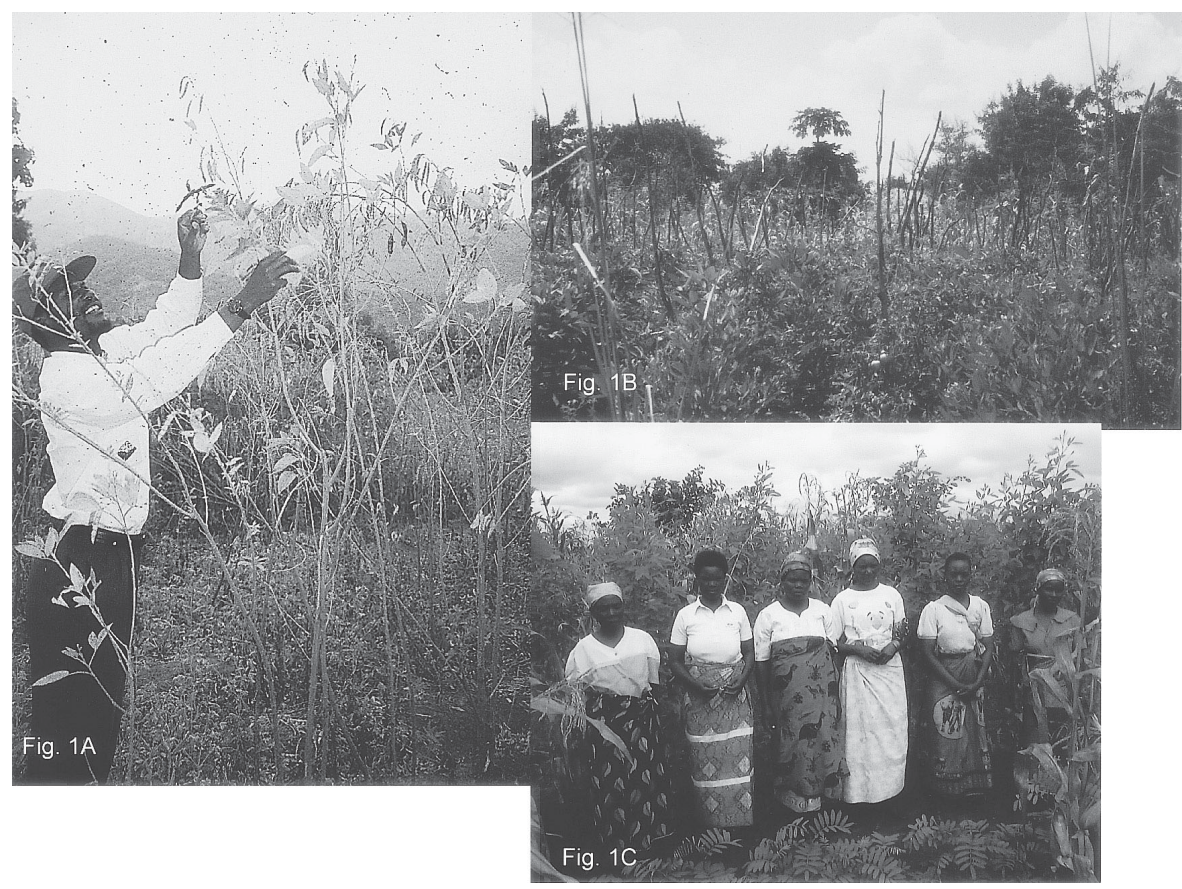

Fig. 1. (A) Pigeon pea breeder examining grain yield of an improved cultivar of pigeon pea (ICP9145) in an on-farm adaptive test, Dedza, Malawi. (B) Pigeon pea/tomato intercrop in a farmer's field, Mangochi, Malawi. (C) Visitors to a test plot evaluating a corn/pigeon pea intercrop for soil fertility and food production potential, Southern Malawi. 
the Indian subcontinent. India is the major producer and user of pigeon pea, accounting for over $80 \%$ of the world's crop (Food and Agriculture Organization, 2000). Pigeon pea prominence may be underestimated. It is widely grown as a household vegetable or backyard crop, as an intercrop and as a boundary marker - production systems not generally included in agricultural statistics. For example, pigeon pea has been recorded as present in 40 African countries (Nene and Sheila, 1990), yet FAO reports production in only Burundi, Malawi, Tanzania, Kenya, and Uganda (FAO, 2000).

Pigeon pea tends to have fewer pest problems in drier regions, but yields may be reduced by terminal drought (Minja et al., 1999). Pigeon pea has more drought tolerance than many other grain legumes and is able to maintain vegetative growth during consecutive dry months because of osmotic adjustment and a strong taproot that is established during the first few months of growth (Anderson et al., 2001). A key trait contributing to wide-scale adaptation of pigeon pea is a vigorous root system, which is developed in diverse soil types, from coarse sands in the Sahel to alkali clays in India (Reddy, 1990).

\section{PRODUCTION SYSTEMS AND USES}

Pigeon pea is a versatile crop, grown primarily as a vegetable in the Caribbean and South America and as a multi-use grain crop in India and some regions of Africa. Vegetable products include immature pods, and seeds that have just reached physiological maturity, before the green color is lost. The pigeon pea is well balanced nutritionally and an excellent source of protein, whether eaten as a green pea or a dried grain (Faris and Singh, 1990). In addition to protein, pigeon pea provides carbohydrates, and 5-fold higher levels of vitamin A and C than green pea (Pisum sativum L.) (Faris et al., 1987). In addition, pigeon pea is used for fodder, soil fertility enhancement, and erosion control, and for fuel (Fig. 2). Minor uses include indigenous medicinal practices, which generally involve a pain-relieving or soporific effect, and craft use (Morton, 1976; Van der Maesen, 1989).

In the Caribbean and South America, pigeon pea is a major component of field boundaries and market gardens, where immature pods and seeds are harvested as vegetables (Fig. 2). Multiple hand harvests are conducted of intercropped systems with long-duration, tall-statured and indeterminate plant types. Monoculture production of pigeon pea is rare, although yield potential is as high as 11 $\mathrm{t} \cdot \mathrm{ha}^{-1}$ of green pods for vegetable line ICPL24 (Faris et al., 1987). Pigeon pea is widely grown for dahl (processed, dry grain legume) in India and Asia, but the immature green pods are also eaten as a vegetable in Java and parts of India (Faris and Singh, 1990). Pigeon pea is produced as a vegetable or export grain crop in southern and eastern Africa, intercropped with corn and other cereals or occasionally with cash crops, such as tomato (Fig. 1B-C).

Long-duration cultivars are generally planted simultaneously as an intercrop with a cereal at the beginning of the rainy season

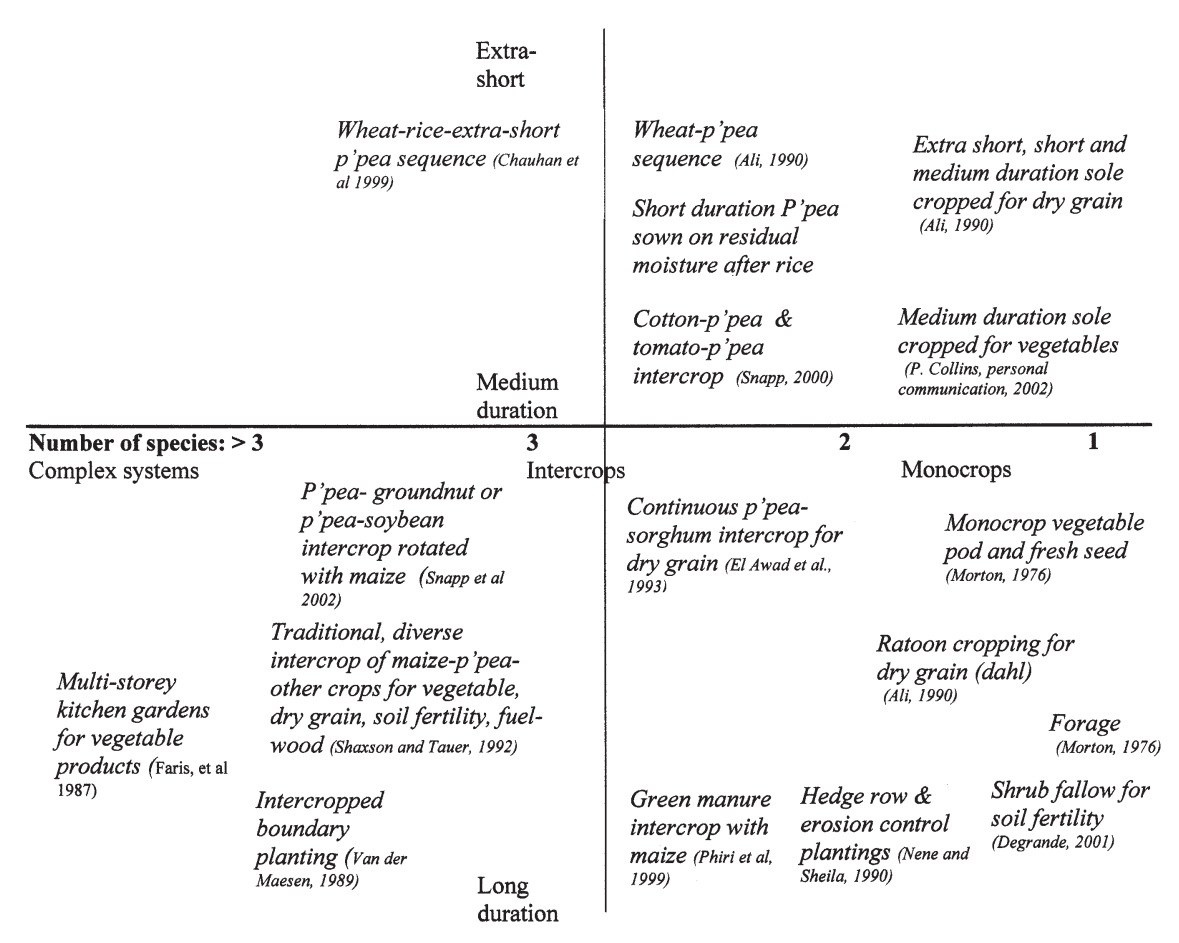

Fig. 2. Schematic matrix to illustrate the range of pigeon pea-based cropping systems in terms of system complexity (number of species involved) and growth habit of the pigeon pea genotypes. Articles that describe the systems are referenced in the figure.

(Nene and Sheila, 1990). Cereals generally are harvested toward the end of the rainy season, and pigeon pea develops rapidly on residual moisture after harvest of the companion crop, or during a second rainy season in a bimodal system. Aratoon system is used in some areas; after harvest the stems are cut back to facilitate re-growth, and a second crop is harvested in the subsequent season (Fig. 2). Landraces, traditional cultivars, and other long-duration, indeterminate types of pigeon pea have an ideal phenotype, slow initial growth and a deep rooting habit. This limits competition within an intercrop. Branching of the pigeon pea shoot occurs late in the season, after harvesting of the cereal crop (Fig. 1C). In dryer areas, and especially in coarser-textured, infertile soils, farmers use wide spacing between plants to limit competition.

A somewhat unusual cropping system is a legume/legume intercrop (Fig. 2). Pigeon pea intercrops with groundnut are traditional in some regions of India, and pigeon pea/soybean or pigeon pea/groundnut (peanut) intercrops are being experimented with in Africa (Natarajan and Mafongoya, 1992; Snapp et al., 2002). Combining a short and long-season legume not only increases yields, but also produces more leafy residues for soil fertility enhancement, and woody stems for starting cooking fires. Pigeon pea grown on-farm, in poor soils and without inputs, produces highly variable yields - from $0.2-2.5 \mathrm{t} \cdot \mathrm{ha}^{-1}$ grain and 1.0 to $3.8 \mathrm{t} \cdot \mathrm{ha}^{-1}$ leaves and stems - where a complementary short-duration legume grown as an intercrop produces an additional 0 to $1.6 \mathrm{t} \cdot \mathrm{ha}^{-1}$ (El Awad et al., 1993; Natarajan and Mafongoya, 1992; Ritchie et al., 2000; Sakala, 1994; Snapp, 2000).
Isolated plant breeding efforts have made progress in developing high yield potential, short duration and short-statured types (Omanga and Summerfield, 1995). Production systems made possible by these novel genotypes include extra-short duration pigeon pea sown on residual moisture after rice (Chauhan et al., 1999). Short-duration cultivars are being experimented with in Kenya as a cash crop after a cereal (Freeman et al., 1999; Jones et al., 2002). Sole cropped systems with limited diversity and high yield potential are typical of shorter-duration genotypes (Fig. 2). However, insect damage can be very high, as the reproductive period occurs only once during the rainy season, when pest populations are high (Fig 3A; Table 1). Resource-poor farmers frequently choose to grow indeterminate genotypes that produce multiple flushes of flowers and pods, to avoid the risk associated with a single flowering period (Snapp and Silim, 2001).

In addition to food uses, pigeon pea has outstanding soil amelioration and conservation properties. The growth habit facilitates soil protection, as the canopy continues to expand for 4 months in the dry season after other crops are harvested; living and senescent pigeon pea leaves may be the only source of cover in semi-arid agroecosystems (Fig. 3B). Pigeon pea nodulates with a wide range of Rhizobium strains and consistently fixes 20 to $140 \mathrm{~kg} \cdot \mathrm{ha}^{-1} \mathrm{~N}$ in infertile soils, substantially higher amounts that is common for tropical grain legumes (Anderson et al., 2001). The vigorous root system explores a large soil volume and recycles nutrients from deep in the profile (Johansen, 1990). Further, pigeon pea root exudates have the unusual ability to solubilize iron-bound phosphorus from some 
soil types (Ae et al., 1990). Pigeon pea residues surveyed in Malawi had high nitrogen and phosphorus contents, from $1.8 \%$ to $4.0 \%$ and $0.22 \%$ to $0.35 \%$, respectively (Snapp, unpublished data). In an earlier study, senescent pigeon pea leaves had lower levels of nitrogen, $\approx 1.4 \%$ (Sakala, 1994). The consequences of biological nitrogen fixation, phosphorus solubility, and effective soil coverage and recycling mechanisms appear to be detectable at a field level; nutrient budgets conducted in corn systems indicated a $30 \%$ increase in phosphorus and nitrogen status with introduction of pigeon pea (Snapp, 1998).

Pigeon pea leaves are also excellent fodder, as shown in a recent study of forage potential for the Great Plains (Rao et al., 2002). It is not surprising that pigeon pea characteristics that promote soil fertility benefits, such as low lignin levels and high nitrogen content, are associated with high quality livestock feed. On smallholder farms in Malawi, goat and cattle preferentially feed on pigeon pea residues (Fig. 3C). Livestock control issues are frequently debated among communities that are experimenting with growing long-duration pigeon pea. Trade-offs can occur between use of pigeon pea as a fodder and a food source (Snapp et al., 2002).

\section{PIGEON PEA POTENTIAL}

The potential for wider uptake of pigeon pea is indicated by an expanding global market for pigeon pea products (Jones et al., 2002). This market is largely influenced by the Indian diaspora. African countries that can produce pigeon pea during the off-season for production on the India sub-continent have a competitive advantage to export whole grain to India; exports have increased at $3 \%$ a year for the last decade, despite the high transportation costs (Freeman et al., 1999). In addition, in the Caribbean region there is persistent demand for vegetable pods and peas, both canned and fresh. Indian and Afro-Caribbean communities around the globe offer new markets for dahl. A rapidly expanding, novel market is the demand for organic foods in North American and European cities (Jones et al., 2002). However, an organic market requires investment in certification procedures that may be cost-prohibitive for widely dispersed farmers (Toomey et al., 2000).

Novel institutional arrangements are being developed that foster closer connections between producers and markets. An example is the export of vegetable pigeon peas from Kenya to Europe. Cooperative marketing arrangements between importers and smallholders have built upon investments in refrigerated transport, crop advisors and communication channels to improve consistency and quality of product (Jones et al., 2002). Another example of innovation in the pigeon pea industry is from Malawi, where over the last decade market share has grown at only $1 \%$ per annum. This is slower than nearby countries, in part due to a poor quality product [pest damage levels in exported pigeon pea grain are frequently over 5\% (Jones et al., 2000)]. This predicament was

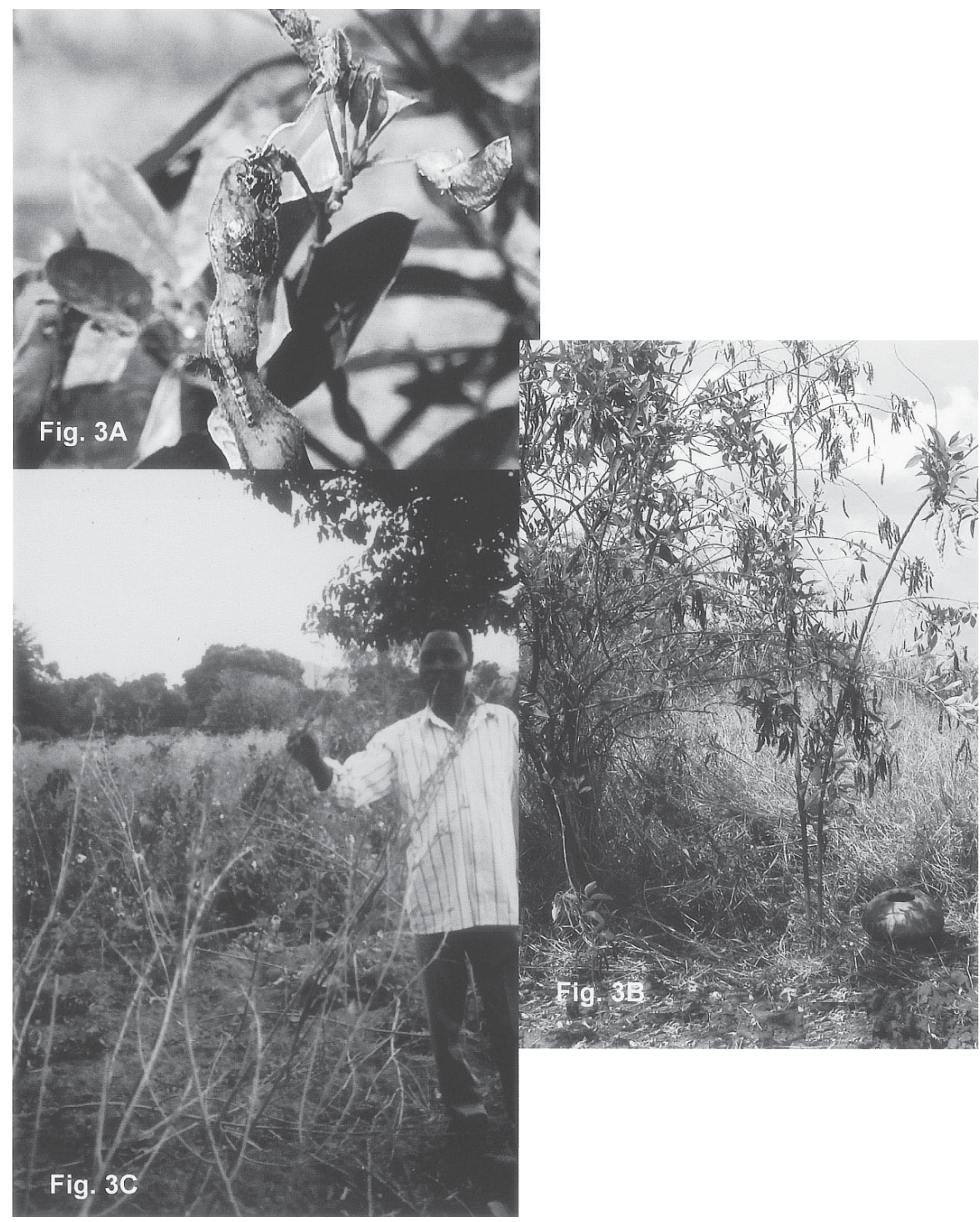

Fig. 3. (A) Pod damage to pigeon pea by borers (Helicoverpa armigera). (B) Pigeon pea residues accumulating under plants late in the growing season, from southern Malawi. (C) Extensive goat damage to pigeon pea crop, leaving only stems at an on-farm test plot along the lakeshore in Mangochi, Malawi.

an incentive for an organization of processors and exporters to be launched in 1999, the "Grain and Legumes Development Association Limited"(GALDAL). Located in southern Malawi, GALDAL has developed standards and improved quality for pigeon pea products, as well as exploring new markets (Jones et al., 2002). However, new farmer cooperatives may also be required (Table 2). Smallholder organization could help reduce transaction costs and consolidate and improve crop quality, while building linkages directly to processors and assisting farmers to retain a significant portion of the product price.

Maintaining and producing a high quality product is critical to building markets (Toomey et al., 2000). This includes meeting standards for grain color, size, processing ability, and minimal pest damage (Jones et al., 2000). New cultivars such as wilt-resistant ICEAP00040 are available that are adapted to Eastern and Southern African agroecozones, and help meet the color, size and processing requirements of processors (Table 2). New, shorter-duration cultivars are also required that allow different marketing windows to be met, and secure the region's reputation as a consistent supplier (Jones et al., 2002).

Beyond the potential for export, the drought-tolerant pigeon pea has a unique role in meeting food security needs of subsistence farmers in climatically risky regions. What particularly recommends pigeon pea is the ability to produce fuel, fodder, and food on rocky or barren and infertile sites. On-farm trials have documented that pigeon pea can produce over $2 t \cdot h^{-1}$ of high-quality residues without any fertilizer inputs, on degraded soils and steep mountain slopes of Southern Malawi, providing one of the only cost-effective and sustainable sources of nutrients for poorer farmers (Kanyama-Phiri et al., 1998; Snapp et al., 1998). Further, corn grain yields after a pigeon pea fallow reflect nitrogen fertilizer equivalency of $\approx 50 \mathrm{~kg} \cdot \mathrm{ha}^{-1} \mathrm{~N}$ in Malawi and Benin studies (MacColl, 1989; Versteeg and 
Koudokpon, 1993). Yield enhancement of cereals after a pigeon pea fallow has also been observed in Kenya and Cameroon (Degrande, 2001; Onim et al., 1990).

\section{CHALLENGES}

There are barriers to expanding pigeon pea production, including the major biotic constraint of insect infestations. In humid regions insect pests cause considerable seed damage, from $14 \%$ to $69 \%$ in recent surveys (Minja et al., 1999). Pod suckers and borers are the primary pests (Fig. 3A). Despite considerable effort to develop resistance, new cultivars can be highly susceptible to pests, as observed in onfarm trials conducted in Malawi (Ritchie et al., 2000), and in Kenya (Table 1). Only cultivars that mature during the dry season have low damage levels. This is an avoidance strategy, as reproduction occurs when pest levels are low. Postharvest losses are highly variable, but loss levels from storage bruchids (Coleoptera) can be $>90 \%$ (Silim-Nahdy, 1995). Improved pest tolerance is urgently needed and selection trials are being conducted in Kenya, complemented by long-term research on feeding stimulants in India (Snapp and Minja, 2002). About one-quarter of growers in Kenya are able to control pigeon pea pests through pesticide use; however, pesticide use among smallholders is almost nil elsewhere (Minja et al., 1999). A more affordable option may be the use of local plant materials with pesticidal properties. A promising candidate is Tephrosia vogelii leaf extract spray, which has potential to control pod suckers and borers in Malawi and Kenya (Minja, 2001), and in Uganda (Silim-Nahdy, 1995). However, the phyto-insecticide product from Tephrosia is highly unstable, which may restrict use to confined settings such as postharvest control of bruchids (Snapp and Minja, 2002).

Other biological constraints to pigeon pea production include fungal disease incidence. Fusarium wilt was mentioned as a major problem by $42 \%$ of farmers interviewed in southern and eastern Africa (Minja et al., 1999). Resistant cultivars are available to combat Fusarium wilt; however, the quality traits of improved cultivars have not always been acceptable to processors, or to farmers (Snapp and Silim, 2001).

Goat and cattle destruction of pigeon pea was a primary constraint to adoption of pigeon pea in central Malawi (Snapp et al., 2002). Pigeon pea is a valued fodder source in some locales, but grain production becomes problematic if livestock are not intensively supervised. In on-farm trials in areas new to pigeon pea production, the plant frequently survived for a month or two after the rains stopped, but goats or cattle grazed it just before harvest (Snapp et al., 2002; Fig. 3C). If cold tolerance were bred into the cultivars, medium-duration pigeon pea could be used to avoid this lateseason problem.

Pigeon peas are used within complex systems, involving intercropping, relay cropping and double cropping, and quality traits are frequently as important as yield potential.

Table 1. Seed damage (\%) from pod-sucking insects on unsprayed pigeon pea genotypes and yield performance at Kiboko, Eastern Kenya (E.M. Minja, unpublished data, 2001)

\begin{tabular}{lccc}
\hline Genotype & $\begin{array}{c}\text { Days to 75\% } \\
\text { maturity }\end{array}$ & $\begin{array}{c}\text { Seed } \\
\text { damage }(\%)\end{array}$ & $\begin{array}{c}\text { Grain yield } \\
\left(\mathrm{t} \cdot \mathrm{ha}^{-1}\right)\end{array}$ \\
\hline ICEAP 00070 & $121 \mathrm{a}$ & $29 \mathrm{~b}$ & $0.3 \mathrm{a}$ \\
ICP 7194-1-S4 & $130 \mathrm{ab}$ & $29 \mathrm{~b}$ & $0.3 \mathrm{a}$ \\
ICEAP 00540 & $149 \mathrm{ab}$ & $26 \mathrm{~b}$ & $0.6 \mathrm{a}$ \\
ICP 6927 & $157 \mathrm{ab}$ & $29 \mathrm{~b}$ & $0.3 \mathrm{a}$ \\
ICEAP 00068 & $167 \mathrm{ab}$ & $27 \mathrm{~b}$ & $0.2 \mathrm{a}$ \\
ICP 7946-E-EB & $171 \mathrm{ab}$ & $26 \mathrm{~b}$ & $0.2 \mathrm{a}$ \\
ICP 7176-5 & $181 \mathrm{ab}$ & $62 \mathrm{c}$ & $1.6 \mathrm{~b}$ \\
ICEAP 00020 & $290 \mathrm{c}$ & $5 \mathrm{a}$ & $1.8 \mathrm{~b}$ \\
Average & $171 \mathrm{ab}$ & $29 \mathrm{~b}$ & $0.7 \mathrm{a}$ \\
Standard deviation & 52 & 15 & 0.7 \\
\hline
\end{tabular}

Plant breeders have not always taken into consideration the wide range of niches that pigeon pea fills, from home consumption of pea pods to export for dahl (Fig. 2). Adoption of shortduration cultivars has been largely restricted to Asia, where the new crop type is double cropped with wheat or rice. Almost no adoption has occurred in Africa or the Caribbean where pod and seed quality criteria varies greatly for home consumption, local markets, and export markets. Arecent review of pigeon pea research in the Caribbean revealed that consumer preferences for bright green pods, and pest resistance requirements, were not adequately addressed by new cultivars (http://www.new-agri.co.uk/ 99-5/focuson/focuson8.html). Kenyan farmers also have strong trait preferences, including a late branching habit that reduces competition with a companion crop, and large seeds that cook rapidly (Snapp and Silim, 2001).

Access of farmers to sufficient quantity of seed is another barrier to widespread adoption. There is no commercial market from which farmers can purchase improved pigeon pea seed (Tripp, 2000). Farmers save pigeon pea seed and on occasion purchase grain from local markets to use as seed, a common practice for grain legumes (Cromwell et al., 1992). This can make profitable production of pigeon pea seed challenging, which limits involvement by the formal seed sector. A range of approaches may be needed, including local seed multiplication efforts and linkages between growers and processors to improve access to seeds and other inputs (Jones et al., 2000; Tripp, 2000). Smallscale enterprise efforts to provide farmers with source seed must not be undermined; seed distribution efforts supported by government or relief operations should strengthen local efforts and not undercut prices (Tripp, 2000).

Barriers to wider production of pigeon pea include requirements for consistent supply and high quality. Lower transaction costs are needed, as well as up-to-date market intelligence that documents end-user requirements. High transaction costs are common, as illustrated in Table 2; a chain of marketers and transporters is shown, where little value is added at each step. Transaction costs could be reduced through innovations in production and institutional arrangements. Processors, exporters, and farmers need to work together on a quality product, and on analysis of comparative advantages for different markets (Jones, et al., 2002; Toomey et al., 2000). NGOs and government researchers and extension staff can play a role in facilitating farmers' involvement and communication channels with buyers, by helping farmers form market organizations, and training them in basic business skills.

\section{A CASE STUDY FROM MALAWI}

Work over the last decade in Malawi, amongst some of the poorest farmers in the world, indicates the potential of pigeon pea to improve farm profitability, and enhance soil fertility (Snapp et al., 2002). The lessons learned from efforts to promote wider adoption of pigeon pea in Malawi provide a model for other developing countries. Pigeon pea is grown as an intercrop with corn in southern Malawi, where it accounts for $\approx 20 \%$ of household income among poor farmers (Orr et al., 2000). It is also a constituent of boundary plantings and vegetable gardens in Northern Malawi, yet pigeon pea is rarely seen in Central Malawi (Fig. 4). The intensively used landscape of subsistence agriculture in the southern most regions of Malawi may be sustained, in part, by biological nitrogen fixation and soil conserving properties of pigeon pea (Kanyama-Phiri et al., 1998; Shaxson and Tauer, 1992). Recently, pigeon pea has been tested in country-wide adaptive trials among a suite of dual-purpose legumes with potential to improve soil fertility and food security (Ritche et al., 2000; Snapp et al., 2002; Fig. 1C). A 3-year study at 40 farm sites found pigeon pea residues provided 30 to $70 \mathrm{~kg} \cdot \mathrm{ha}^{-1} \mathrm{~N}$ and were particularly suited to the resource base of smallholders. After 2 years of intercrop or rotation with pigeon pea, corn yields increased by $\approx 0.3-1.6 \mathrm{t} \cdot \mathrm{ha}^{-1}$ compared with sole-cropped corn (Snapp and Silim, 2001). Mucuna [Mucuna pruriens (L.) DC var. utilis] and Tephrosia vogelii also produced substantial amounts at residues and enhanced corn yields, but performance was not as consistent across locations (Snapp et al., 2002). Note that residues have minimal benefits if they are burned, instead of incorporated, or if they are used on degraded sites (Kanyama-Phiri et al., 2000; Snapp, 1998). Soil fertility benefits from incorporating pigeon pea in corn-based systems have been documented in earlier studies (MacColl, 1989; Onim et al., 1990).

Interestingly, farmers were primarily interested in pigeon pea as a potential new market opportunity and a weed suppression agent; soil fertility benefits were secondary (Snapp et al., 
Table 2. Procedure for developing an integrated system for pigeon pea market expansion, addressing communication, marketing and organizational linkages, as well as production improvements.

\begin{tabular}{|c|c|c|c|}
\hline & Supply & Linkages & Demand \\
\hline Current system & $\begin{array}{l}\text { Geographically dispersed smallholders } \\
\text { produce a corn/pigeon pea intercrop } \\
\text { with traditional cultivars (grain yield: } \\
\approx 0.1 \text { to } 0.5 \mathrm{t} \cdot \mathrm{ha}^{-1} \text { ). Low-quality product. }\end{array}$ & $\begin{array}{l}\text { Local traders purchase pigeon pea } \\
\text { products at dispersed locations, } \\
\text { sell to regional and interregional } \\
\text { market middlemen }\end{array}$ & $\begin{array}{l}\text { Processors and exporters purchase } \\
\text { from market traders, process } \\
\text { product, and export to markets } \\
\text { Local consumption is limited. }\end{array}$ \\
\hline
\end{tabular}

Production system/ cultivar innovations

Marketing innovations and new institutional relationships

References
Outstanding cultivars tested on-farm: 1) ICP9145 (1.0-3.5 t ha $^{-1}$ biomass), recommended fodder or green manure 2) ICEAP00040 (0.4-1.8 $\mathrm{t} \cdot \mathrm{ha}^{-1}$ grain yield) with high-quality seeds

Establish farmer market organizations to: 1) Leverage stable, higher product prices through quantity and quality; 2) Obtain market information on regional, prices, quality, and product opportunities

Snapp and Silim, 2001; Ritche et al., 2000; Snapp, 2000; Orr et al., 2000

\section{NGOs, Government and}

Univ. researchers collaborate to test new cultivars with farmer input on product quality, while promoting seed production

Facilitate new marketing arrangements: 1) Develop farmer business skills, organizations \& links to larger buyers; 2) Improve communication among all parties
Processors evaluate new cultivars, ICEAP 00040 favored due to dehulling traits, excellent processing properties, color, and size

Processors and exporters form new organization to: 1) Improve market quality standards and preferential payment; 2) Learn more re: export market quality, new markets.

Jones et al., 2000; Toomey et al., 2000
2002). Monitoring of weed population density at 35 on-farm plots indicated that a pigeon pea intercrop reduced weed pressure by an average of $38 \%$, compared with monoculture corn (Snapp, 2000). Marginal returns analysis from 3 years of Malawi adaptive trials indicated that pigeon pea/groundnut intercrops rotated with corn had returns $>200 \%$, and pigeon pea/corn intercrops had returns $>450 \%$, compared with monoculture corn (Table 3; and see Kamanga, 1999). Similar results were obtained in onfarm studies with pigeon pea in Cameroon (Degrande, 2001). Interestingly, not only were economic returns comparable with those in Malawi, but strong interest was also documented among Cameroon farmers in weed suppression, and in new market opportunities.

Economic analysis indicates the potential for substantial, positive returns from wider adoption (Table 3 ), yet pigeon pea is primarily restricted to southern Malawi (Fig. 4). A survey of 240 Malawian farmers revealed that insufficient access to markets and lack of consistent seed supply were major constraints to planting of more legumes (Snapp et al., 2002). In addition, farmers note persistent problems with insect and livestock damage that reduce yields of experimental pigeon pea plantings (Snapp and Minja, 2002). Farmer innovators in Mangochi (Malawi lakeshore site) have reduced damage from pod sucking bugs by intercropping shortduration pigeon pea with tomato (Lycopersicon esculentum Mill.) to obtain dual coverage with pesticides (Fig. 1B). Farmers were introduced to the idea of dual coverage through on-farm research that fostered experimentation with pigeon peas by cotton (Gossypium hirsutum L.) growers, who have greater experience and access to pesticides (Snapp, 2000). Although cotton was not a successful pigeon pea intercrop, farmers in the area have continued to experiment with intercropping short-duration cultivars with tomatoes, and as sole crops (Fig. 1B). Enterprising farmers are also starting to grow improved long-duration cultivars such as ICEAP00040, which perform well on-farm and meet processor quality requirements (Table 2 ). However, adoption has not occurred in many nearby regions.

In conclusion, many of the challenges and opportunities faced in Malawi hold throughout
Snapp et al., 2002; Tripp, 2000; Jones et al., 2002

\section{Elevation Zones \& Agricultural Development Divisions}

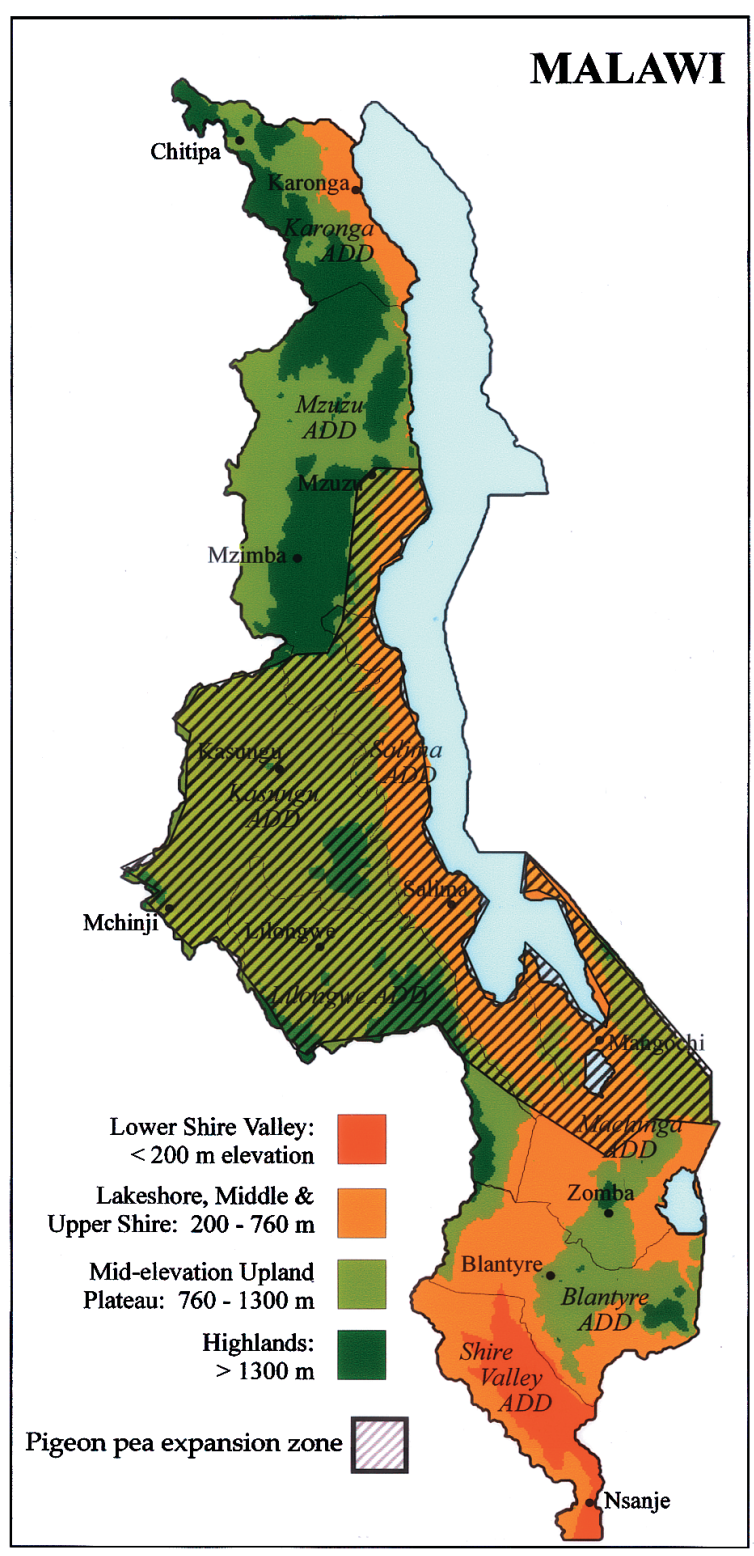

Fig. 4. Map of Malawi, showing elevation zones and central region where pigeon pea is currently not grown, but has potential for expansion. 
Table 3. Marginal rate of return from legume integrated cropping systems compared to monoculture, sole-cropped corn (CIMMYT, 1988). Data from on-farm trials at two sites in Central and Southern Malawi, 1997/98-1999/2000, $\mathrm{n}=80$ (unpublished data, J. Rusike and S. Snapp, 2000; on-farm trial yields reported previously, Snapp et al., 2002).

\begin{tabular}{lcc}
\hline & \multicolumn{2}{c}{ Site } \\
\cline { 2 - 3 } & Chisepo & Mangochi \\
\cline { 2 - 3 } Cropping system & 239 & 39 \\
\hline Corn/Tephrosia relay intercrop & 649 \\
Corn/pigeon pea intercrop & 220 & 184 \\
Groundnut/pigeon pea intercrop & & \\
and corn rotation & & \\
\hline IDepartment of Horticulture, Michigan State Univ., East Lansing, MI 48824- \\
1325.
\end{tabular}

sub-Saharan Africa. To achieve greater dissemination of pigeon pea will require promotion of appropriate short-duration cultivars and pest management systems. However, plant breeding and selection is required to develop shorter-duration genotypes that have desired seed quality traits and tolerance to pests and cool temperatures. A few improved cultivars of long-duration pigeon pea are available for wider use in Africa: ICP9145 and ICEAP00040 have resistance to Fusarium wilt and superior productivity on-farm. New institutional relationships may also be required to improve communication among consumers, processors, researchers and farmers, and to build a supply of high quality pigeon pea products that are linked to appropriate markets. The result could be widespread adoption of this versatile vegetable that improves soil and human nutrition.

\section{Literature Cited}

Ae, N., J. Arihara, K. Okada, T. Yoshihara, and C. Johansen. 1990. Phosphorus uptake by pigeon pea and its role in cropping systems of the Indian subcontinent. Science 248:477-480.

Ali, M. 1990. Pigeonpea: Cropping systems, p. 303-348. In: Y.L. Nene, S.D. Hall, and V.K. Sheila (eds.). The pigeon pea. Intl. Crops Res. Inst. for the Semi-Arid Tropics (ICRISAT) and C.A.B. Intl., Oxon, U.K.

Anderson, S., S. Gundel, B. Pound, and B. Triomphe. 2001. Cover crops in smallholder agriculture: Lessons from Latin America. Intermediate Technology Development Group (ITDG) Publishing, London, U.K.

Chauhan, Y.S., W.D. Atukorala, K.D.A Perera, K.D.S.M. Joseph, K.B. Saxena, and C. Johansen. 1999. Adaptation of extra-short-duration pigeon pea in the short rainy season of a tropical bimodal rainfall environment. Expt. Agr. 35:87-100.

CIMMYT. 1988. From agronomic data to farmer recommendations: An economics training manual. Completely revised edition. Mexico, D.F.

Cromwell, E., E. Friis-Hansen, and M. Turner. 1992. The seed sector in developing countries: Aframework for performance analysis. Overseas Dev. Inst. Working Paper No. 65. Overseas Dev. Inst., Chatham, U.K.

Degrande,A. 2001. Farmer assessment and economic evaluation of shrub fallows in the humid lowlands of Cameroon. Agroforestry Systems 53:11-19.

ElAwad,H.O.,A.K. Osman, M.A.H. Khair, and M.M. Balala. 1993. Pigeon pea research for rainfed and irrigated production systems in Western and Cen- tral Sudan, p. 85-89 In: S.N. Silim, S. Tuwafe, and L. Singh (eds.). Improvement of pigeon pea in Eastern and Southern Africa. Ann. Res. Planning Mtgs. 1993. Bulawayo, Zimbabwe 25-27 Oct. 1993. Intl. Crops Res. Inst. for the Semi-Arid Tropics (ICRISAT), Andhra Pradesh, India.

Faris, D.G., K.B. Saxena, S. Mazumdar, and U. Singh. 1987. Vegetable pigeon pea: A promising crop for India. Patancheru, A.P. 502 324, India: Intl. Crops Res. Inst. for the Semi-Arid Tropics (ICRISAT). Andhra Pradesh, India.

Faris, D.G. and U. Singh. 1990. Pigeon pea nutrition and products, p. 401-433. In: Y.L. Nene, S.D. Hall, and V.K. Sheila (eds.). The pigeon pea. Intl. Crops Res. Inst. for the Semi-Arid Tropics (ICRISAT) and CAB Intl., Oxon, U.K.

Freeman, H.A., R.B. Jones, S.N. Silim, and M.A. Ochere. 1999. The pigeonpea sub-sector in Kenya. Mimeo.

Johansen, C. 1990. Pigeon pea: Mineral nutrition, p. 209-231. In: Y.L. Nene, S.D. Hall, and V.K. Sheila (eds.). The pigeon pea. Intl. Crops Res. Inst. for the Semi-Arid Tropics (ICRISAT) and CAB Intl., Oxon, U.K.

Jones, R., A. Likoswe, and H.A. Freeman. 2000. Improving poor farmers' access to technologies and markets for pigeonpea in Malawi, p. 150-157. In: J.M. Ritchie (ed.). Integrated crop management research in Malawi: Developing technologies with farmers. Proc. final workshop of the farming systems integrated pest management project. Natural Resources Inst., Chatham, U.K.

Jones, R., A. Likoswe, and H.A. Freeman. 2002. Improving the access of small farmers in Eastern and Southern Africa to global pigeonpea markets. Agr. Res. and Ext. Network. Network Paper No. 120, Overseas Development Inst., Chatham, U.K.

Kamanga, B. 1999. Soil fertility management and socioeconomic components of farmer participatory research in a Southern Malawi watershed. M.Sc. Thesis, Dept. of Crop Science, Bunda College of Agr., Univ. of Malawi.

Kanyama-Phiri, G.Y., S.S. Snapp, and S. Minae. 1998. Partnership with Malawian farmers to develop organic matter technologies. Outlook on Agr. 27:167-175.

MacColl, D. 1989. Studies on maize (Zea mays L.) at Bunda, Malawi. II. Yield in short rotation with legumes. Expt. Agr. 25:367-374.

Minja, E.M. 2001. Yield losses due to field pests and integrated pest management strategies for pigeon pea-A synthesis, p. 48-54. In: S.N. Silim, G. Mergeai, and P.M. Kimani (eds.). Status and potential of pigeon pea in eastern and southern Africa: Proc. of a regional workshop, 12-15 Sept. 2000, Nairobi, Kenya. B-5003 Gembloux, Belgium: Gembloux Agricultural Univ.; and Patancheru 502 324, Intl. Crops Res. Inst. for the Semi-Arid Tropics (ICRISAT), Andhra Pradesh, India.

Minja, E.M., T.G. Shanaower, J.M. Songa, J.M. Ongaro, W.T. Kawonga, P.J. Mviha, F.A. Myaka, S. Slumpa, H. Okurut-Akol, and C. Opiyo. 1999. Studies of pigeon pea insect pests and their management in Kenya, Malawi, Tanzania, and Uganda. African Crop Sci. J. 7:59-69.

Morton, J.F. 1976. The pigeon pea (Cajanus cajan Millsp.), a high protein tropical bush legume. HortScience 11:11-19.

Natarajan, M. and P.L. Mafongoya. 1992. A study on intercropping of pigeon pea (Cajanus cajan L. Mill sp.) with maize, sunflower and groundnut in Zimbabwe. Zimbabwe J. Agr. Res. 30: $163-171$.

Nene, Y.L. and V.K. Sheila. 1990. Pigeon pea: Geography and importance, p. 1-14. In: Y.L. Nene, S.D. Hall, and V.K. Sheila (eds.). The pigeon pea. Intl. Crops Res. Inst. for the Semi-Arid Tropics (ICRISAT) and CAB Intl., Oxon, U.K.

Omanga, P.A., R.J. Summerfield, and A. Qi. 1995. Flowering of pigeon pea (Cajanus cajan) in Kenya: Responses of early maturing genotypes to location and date of sowing. Field Crops Res. 41:25-34.

Onim, J.F.M., M. Matuwa, K. Otieno, and H.A. Fitzhugh. 1990. Soil fertility changes and responses of maize and beans to green manures of leucaena, sesbania and pigeon peas. Agroforestry Syst. 12:197-125.

Orr, A., B. Mwale, and D. Saiti. 2000. Markets and livelihoods: Lessons from farming systems research in Blantyre/Shire Highlands. p 279-291. In: J.M. Ritchie (ed.). Integrated crop management research in Malawi: Developing technologies with farmers. Proc. of the final workshop of the farming systems integrated pest management project. Natural Resources Inst., Chatham, U.K.

Phiri, R.H., S.S. Snapp, and G.Y. Kanyama-Phiri. 1999. Soil nitrate dynamics in relation to nitrogen source and landscape position in Malawi. Agroforestry Syst. 47:253-262.

Rao, S.C., S.W. Coleman, and H.S. Mayeux. 2002. Forage production and nutritive value of selected pigeonpea ecotypes in the southern Great Plains. Crop Sci. 42:1259-1263.

Reddy, L.J. 1990. Pigeon pea: Morphology, p. 47-87 In: Y.L. Nene, S.D. Hall, and V.K. Sheila (eds.). The pigeon pea. Intl. Crops Res. Inst. for the Semi-Arid Tropics (ICRISAT) and CAB Intl., Oxon, U.K.

Ritche, J.M., S. Abeyakekera, C.S.M. Chanika, S.J. Ross, C.B.K. Mkandawire, T.H. Maulana, E.R. Shaba, and T.T.K. Milanzi. 2000. Assessment of improved pigeonpea cultivars under smallholder management, p.180-189. In: J.M. Ritchie (ed.). Integrated crop management research in Malawi: Developing technologies with farmers. Proc. of the final workshop of the farming systems integrated pest management project. Natural Resources Inst., Chatham, U.K.

Sakala, W.D. 1994. Crop management interventions in traditional maize pigeon pea intercropping systems in Malawi. M.Sc. Thesis, Bunda College of Agr., Univ. of Malawi, Lilongwe, Malawi.

Shaxson, L. and L.W. Tauer. 1992. Intercropping and diversity: An economic analysis of cropping patterns on smallholder farms in Malawi. Expt. Agr. 28:211-228.

Sheldrake, A.R. and A. Naranyanan. 1979. Growth, development and nutrient uptake in pigeon peas (Cajanus cajan). J. Agr. Sci. 92:513-526.

Silim, S.N. and P.A. Omanga. 2001. The response of short-duration pigeon pea lines to variation 
in temperature under field conditions in Kenya. Field Crops Res. 72:97-108.

Silim-Nahdy, M. 1995. Biotic and abiotic factors influencing the biology and distribution of common storage pests in pigeon pea. PhDDiss., Univ. of Reading, U.K.

Snapp, S.S. 1998. Phosphorus and sustainability of sub-Saharan Africa smallholder farms, p. 59-72. In: J.P. Lynch and J. Deikman (eds. ). Phosphorus in plant biology: Regulatory roles in molecular, cellular, organismic and ecosystem processes. Amer. Soc. Plant Physiol., Madison, Wis.

Snapp, S.S. 2000. Final Report to The Rockefeller Foundation on research grant 'Methodology to develop practical soil fertility technologies through farmer/researcher partnerships.' Intl. Crops Res. Inst. for the Semi-Arid Tropics
(ICRISAT), Lilongwe, Malawi, mimeo. p. 39. Snapp, S.S. and E. Minja. 2002. Integration of IPM in integrated crop management: Experiences from Malawi. In: K. Maredia (ed.). Global IPMHandbook. CAB Intl., Oxon, U.K. (In press.)

Snapp, S.S., D.D. Rohrbach, F. Simtowe, and H.A. Freeman. 2002 Sustainable soil management options for Malawi: Can smallholder farmers grow more legumes? Agr. Ecosys. Environ. (In press.)

Snapp, S.S. and S.N. Silim. 2001. Farmer preferences and legume intensification for low nutrient environments. Plant and Soil (In press.)

Toomey, D.C., P.A. Sterns, and C. Jumbe. 2000 The impact of improved grades and standards on the export potential of targeted commodities in Malawi. Inst. for Food and Agr. Standards,
U.S.A.I.D. project report, mimeo. p. 104.

Tripp, R. 2000. Strategies for seed system development in sub-Saharan Africa: A study of Kenya, Malawi,Zambia, and Zimbabwe, Socioeconomics and Policy Program, Working Paper Series \#2, Intl. Crops Res. Inst. for the Semi-Arid Tropics (ICRISAT) and Overseas Development Inst., Chatham, U.K.

Van der Maesen, L.J.G. 1989. Cajanus cajan (L.) Millsp., p. 39-42. In: L.J.G. van der Maesen and S. Somaatmadja (eds.). Plant resources of South-East Asia No 1. Pulses. Pudoc/Prosea, Wageningen, The Netherlands.

Versteeg, M.N. and V. Koudokpon. 1993. Participative farmer testing of four low external input technologies, to address soil fertility decline in Mono province (Benin). Agr. Syst. 42:266-27. 